\title{
AS ESCOLAS E SUAS ENSINAGENS: A DIVERSIFICAÇÃO DE TERRITÓRIOS E IDENTIDADES
}

Após algumas décadas em que tanto a discussão teórica do campo quanto a organização dos currículos em escolas brasileiras pautou-se, predominantemente, na direção da diversidade, das diferenças e das singularidades, o último ano e meio é marcado pela retomada da discussão sobre base nacional comum [curricular].

Nesse contexto, a escola pública, como representante da condição social da igualdade, equidade e universalidade da formação dos sujeitos, reafirma sua posição estratégica. Isso se nota tanto na formulação de políticas educativas mais amplas quanto nas que especificamente tratam tanto do currículo quanto da avaliação escolar.

São bem conhecidas as relações históricas entre currículo e avaliação, especialmente na organização do trabalho pedagógico nas escolas. Vários estudos acadêmicos indicaram características sobre a avaliação escolar que tanto permitiam condições de ensino e de aprendizagem mais discriminatórias, quanto mais includentes, reflexivas e transformadoras. Esses estudos acadêmicos, em linhas gerais, indicavam o caráter produtor e reprodutor de práticas sociais nessas relações entre currículo e avaliação, destacando a necessidade de se construir o trabalho autônomo, intelectual e transformador pelos/com os professores.

O que se nota de diferente, a partir do estabelecimento de sistemas de avaliação e de aprendizagem centralizados, é que os papeis do professor e da comunidade escolar em geral alijam-se de uma participação mais articulada e autoral. Ou seja, as equipes pedagógica e de gestão das escolas trabalham com a avaliação externa na direção de responder àquilo que interessa a essa avaliação e, em menor grau, ao que interessaria mais fortemente aos projetos políticos e pedagógicos das escolas, parte dos quais o currículo constitui. Esse processo, entretanto, não gera movimentos que isolem o que seja "externo" e "interno" às escolas; dizendo de outra maneira, toda a estruturação das avaliações externas que visam verificar a performance, a eficiência e os resultados dos processos pedagógicos escolares entretecem-se com a seleção social, organização de conteúdos e métodos, recortes na formação das identidades dos estudantes e ênfase na função social da escola, que os currículos expressam.

A elaboração de novos documentos de orientação e referência curriculares - propostas, diretrizes, planos, ensaios, ideias, experiências - deve ser sensível e comprometida na direção de considerar que as professoras/os professores têm, com suas profissões, ações que vão muito além de aspectos técnicos, operacionais e de efetivação (aplicação ou colocar em prática) pensamentos, atividades e ideias vindos de outro lugar. 
As professoras/os professores produzem conhecimento nos cotidianos das escolas e nas diferentes ações pedagógicas que realizam. A elaboração dos documentos curriculares necessitaria não apenas contar com a participação de professoras/es, mas especialmente levar em consideração essas dimensões produtivas e criativas do seu trabalho. Com isso, poder-seia constituir interações de mão dupla (ou tripla, ou em multiplicidades) entre os documentos curriculares que buscam algo mais geral e que contemple a educação "para todos" e as singularidades, os acontecimentos e as particularidades que a educação para "cada uma/um" traz como potência.

A proposta de uma base comum curricular recoloca no centro das atenções a tensão das relações entre currículos e conhecimentos por meio da seleção do que deveria ser comum a todas as escolas e ao que deveria ser diferente (em outras palavras, currículo mínimo e parte diversificada). Do ponto de vista da história do currículo e das disciplinas escolares, há evidências muito bem detalhadas nas pesquisas acadêmicas que nos permitem perceber que o currículo mínimo, composto por determinadas disciplinas, é um campo de disputa e de busca de hegemonização. A discussão sobre comum e diversificado, em certa medida, escamoteia o que viria a ser o "grande" problema - se existe - da relação entre currículo e conhecimento.

O que se nota é a disputa, cada vez maior, do que "precisaria" ser contemplado como mínimo; e nesse jogo de poder e de significação, um olhar analítico buscaria responder como as disciplinas até então estáveis no currículo escolar e as com menor tradição curricular se veem em busca de garantir sua presença. Com tal ênfase entre parte comum e parte diversificada, a parte diversificada fica sempre subalternizada ou submissa e nos centramos a olhar como ela poderia ser "incluída" no currículo.

Também com o movimento de produção de uma base nacional comum reposicionamse as conexões entre identidades e diversidade na territorialização de sentidos para o nacional. A diversidade vem sendo recortada, representacionalmente, como um tipo de variação plural de um "único" em busca de dar visibilidade às diferenças. É como se ela emergisse - reativa e positivamente - do contato com o comum.

Uma tensão que parece importante de se destacar está na polarização entre o único, o essencial, o idêntico e o diverso, o diferente; polarização essa que trabalharia, em termos curriculares, na composição de vários diferentes, únicos em si mesmos, sem possibilidades de encontros, transformações, críticas e reflexões a respeito do que seja diverso. Mas, especialmente, da produção do diverso e suas conseqüências que, por exemplo, podem se associar às desigualdades, à discriminação, ao cinismo, à tolerância desinteressada ou à naturalização de que o diverso existe, está dado, e não há sobre o quê discutir.

É inspirador migrarmos do pensamento com/sobre a diversidade para o pensamento da diferença nas discussões sobre currículo e escola. Há acúmulo considerável da produção de pesquisa acadêmica neste campo, que nos dá algumas pistas sobre o quão é importante, pelo menos, colocar a diferença como questão a ser tomada como um problema, debatida e (re)vitalizada. 
Associar diferença com diversidade é uma das possíveis linhas para que esta discussão seja pautada; a diversidade tem sido entendida como uma outra síntese que aglutina as diferenças em um tipo de homogeneidade variada, diversa, cujas marcas dos sujeitos não são apagadas totalmente, mas ainda se "assegurando" que em todo diverso há aspectos comuns que retornariam o pensamento curricular para um humano ideal, utópico.

Seria essa a resultante redundante da base comum nacional?

Este novo número da revista ETD - Educação Temática Digital permite que a leitora/o leitor estendam respostas a essa questão em linhas de multiplicidade à medida que (re)posiciona importantes argumentos, pressupostos e questionamentos - construídos em práticas de pesquisa e de experiências educacionais as mais diferentes - sobre as posições da professora/ do professor (sujeito/autor) e da escola nos engendramentos da educação comprometida com a diferença.

As contribuições aglutinam-se tanto em suas densidades temáticas e metodológicas quanto trilham caminhos por entre condições de produção específicas das pesquisas e das experiências, chamando a atenção, por exemplo, para outras formas de escrita, de narrativas, de papeis estético-políticos que a linguagem tenciona.

Ao lidarem com a pluralidade de focos sobre os fenômenos educativos que, por diferentes nuanças e perspectivas, atravessam a instituição escolar, os sujeitos que a constroem e dela fazem parte e os agenciamentos vários que a significam, os artigos publicados neste novo número permitem deslocamentos invasivos nos estáveis reconhecimentos de escola, de formação de professores e de políticas de suas representações.

Os artigos e suas autoras e autores põem em evidência a urgência do diálogo provocativo das produções em pesquisa do campo da Educação com as 'novas' questões socioculturais e, paradoxalmente, conservadoras dos tempos atuais.

Que a sua leitura seja inspiradora e aguce conversações.

Antonio Carlos Amorim ${ }^{1}$ Agosto/2015

\footnotetext{
1 Editor Científico da ETD - Educação Temática Digital - Faculdade de Educação da UNICAMP Departamento de Educação, Conhecimento, Linguagem e Arte. E-mail: acamorim@unicamp.br
} 
Como citar este documento:

AMORIM, Antonio Carlos. Editorial: As escolas e suas ensinagens: diversificação de territórios e identidades. ETD - Educação Temática Digital, Campinas, SP, v. 17, n. 2, p. 230-233, ago. 2015. ISSN 1676-2592. Disponível em:

〈http://periodicos.sbu.unicamp.br/ojs/index.php/etd/article/view/8639511〉. Acesso em: 31 ago. 2015. 